\title{
Kadar Total Pigmen Klorofil Tanaman Avicennia marina Pada Tingkat Perkembangan Daun yang Berbeda
}

\author{
P.S. Ajiningrum \\ Staf pengajar Prodi Biologi F.MIPA Universitas PGRI Adi Buana Surabaya
}

\begin{abstract}
ABSTRAK
Penelitian ini bertujuan untuk mengetahui kadar klorofil a, kadar klorofil b, kadar klorofil total, rata-rata luas daun api-api (Avicennia marina) dan hubungan keduanya pada tingkat perkembangan daun yang berbeda. Kandungan klorofil diukur dengan spektrofotometer UV-Vis pada $\lambda 649$ dan $665 \mathrm{~nm}$. Kadar klorofil total dihitung dengan rumus Wintermans dan De Mots. Untuk menghitung luas daun digunakan metode gravimetri. Data hasil penelitian yang meliputi perhitungan kadar klorofil total dan luas daun dianalisis untuk mengetahui korelasi antar keduanya menggunakan korelasi bivariat pada taraf signifikan 5\% dengan aplikasi spss. Berdasarkan hasil penelitian yang telah dilakukan, dapat ditarik kesimpulan bahwa kandungan klorofil a, klorofil b dan klorofil total daun api-api berbeda pada tiga daerah perkembangan yang berbeda, yaitu ujung, tengah dan pangkal daun. Rata-rata klorofil total terendah terdapat pada ujung daun yaitu sebesar $5,4 \mathrm{mg} / \mathrm{L}$, sedangkan jumlah yang tertinggi terdapat di bagian pangkal daun yaitu $12,4 \mathrm{mg} / \mathrm{L}$. Rata-rata jumlah luas daun terendah terdapat pada ujung daun yaitu sebesar $25 \mathrm{~cm}^{2}$, sedangkan ratarata jumlah luas daun tertinggi terdapat pada bagian pangkal yaitu sebesar $112 \mathrm{~cm}^{2}$. Hal ini menunjukkan bahwa peningkatan rata-rata luas daun bertambah seiring dengan tingkat perkembangan daunnya. Berdasarkan hasil output yang dihasilkan dari analisis bivariat, hubungan korelasi antara kadar klorofil total dan luas daun ditunjukkan dengan nilai koefisien korelasi 0,948 , sehingga dapat disimpulkan bahwa terdapat korelasi yang positif antara luas daun dan kadar klorofil total yang artinya jika luas daun bertambah di setiap tingkat perkembangan daunnya, maka kandungan klorofil totalnya juga akan semakin meningkat.
\end{abstract}

Kata Kunci: Avicennia marina, klorofil a, kadar klorofil b, klorofil total, luas daun

PENDAHULUAN

Klorofil

merupakan

sebagian besar pigmen yang ditemukan dalam membran tilakoid kloroplas. Pigmen hijau pada daun berperan untuk mengabsorpsi cahaya dalam fotosintesis fase I, yaitu reaksi fotolisis (Salisbury dan Ross, 1995 dalam Gogahu et al (2016). Pigmen klorofil tidak hanya berperan sebagai pigmen fotosintesis, tetapi juga dapat bermanfaat sebagai disinfektan, antibiotik dan sebagai makanan tambahan. Klorofil dapat digunakan sebagai makanan tambahan karena mengandung nutrisi yang dibutuhkan untuk tubuh manusia (Hendriani dan Setiari, 2009). Sumber klorofil di Indonesia sebetulnya sangat melimpah namun pemanfaatannya masih sangat sedikit (Abdilah et al, 2014).

Tanaman Avicennia marina merupakan salah satu jenis mangrove yang masuk ke dalam kategori mangrove mayor. Status tersebut menyebabkan A. marina 
hampir selalu ditemukan pada setiap ekosistem mangrove. Daun $A$. marina menunjukkan perbedaan warna dalam setiap pertumbuhan daunnya. Daun pada pucuk biasanya berwarna hijau mengkilat dan permukaan bawah berwarna hijau abu-abu dan suram. Perbedaan warna daun menunjukkan adanya perbedaan kandungan pigmen daun termasuk pigmen klorofil. Kemampuan daun untuk melakukan fotosintesis semakin lama semakin meningkat sampai daun berkembang penuh dan kemudian mulai menurun secara perlahan. Daun tua yang hampir mati kemudian berubah warnanya menjadi kuning dan tidak mampu berfotosintesis karena klorofil rusak dan fungsi kloroplas hilang. Potensi pada A. marina yang selama ini dikenal oleh masyarakat masih terbatas hanya sebagai tanaman pangan saja. Maka untuk mengetahui manfaat lain dari tanaman ini diperlukan penelitian dengan cara menghitung kadar klorofil total pada tingkat perkembangan daun yang berbeda sebagai data dasar untuk menggali potensi lain mengingat banyaknya manfaat klorofil dari tumbuhan dalam menunjang kehidupan manusia.

\section{METODE PENELITIAN}

Tempat dan Waktu Penelitian

Penelitian dilakukan di Laboratorium Biologi Dasar, Prodi Biologi, Fakultas Matematika dan
Ilmu Pengetahuan Alam Universitas PGRI Adi buana Surabaya.

\section{Bahan Penelitian}

Bahan sampel yang digunakan adalah daun api-api (Avicennia marina) pada tingkat paling atas, tengah dan paling bawah yang masih segar. Bahan kimia yang digunakan adalah alkohol, akuades, es batu dan tissue.

\section{Peralatan Penelitian}

Peralatan yang digunakan adalah kantong plastik, kertas label, alat tulis, timbangan analitik, lumpang dan alu porselin, tabung reaksi, rak tabung reaksi, labu ukur, gelas ukur, saringan, termos es, gunting, aluminium foil, kertas milimeterblok dan spektrofotometer UV-Vis.

\section{Metode Pengumpulan Data}

Kadar klorofil diukur menggunakan alat spektrofotometer UV-Vis. Luas daun diukur menggunakan metode gravimetri yaitu dengan cara membuat replika daun pada kertas milimeterblok dan ditimbang beratnya. Data hasil penelitian yang meliputi perhitungan kadar klorofil total dan luas daun dianalisis menggunakan korelasi bivariat pada taraf signifikan 5\% dengan aplikasi spss.

\section{Ekstraksi Pigmen Klorofil}

Daun dipetik dari pohon, sesuai tingkat perkembangan daun yaitu pucuk, daun yang masih muda dan daun yang sudah dewasa. Daun 
dimasukkan dalam kantong plastik secara terpisah sesuai dengan kelompoknya. Kemudian helaian daun setiap sampel diambil sebanyak 2 gram, dihaluskan dan diekstraksi dengan alkohol 95\% sampai semua klorofil terlarut.

\section{Perhitungan kadar klorofil menggunakan spektrofotometer}

Untuk mengukur klorofil, terlebih dahulu dilakukan kalibrasi terhadap nilai transmitansinya. Nilai transmitan pelarutnya harus dibuat atau diatur $100 \%$, sehingga nilai absorbansi yang dihasilkan saat pengukuran semata-mata ditentukan oleh klorofil sebagai zat terlarutnya (bukan oleh pelarut). Langkahlangkahnya adalah dengan menghidupkan spektrofotometer sebelum digunakan untuk mengukur (20 menit) agar alatnya stabil. Pelarut (aceton/ethanol) dituangkan (sesuai yang digunakan) ke dalam cuvet sampai garis batas. Kemudian permukaan luar tabung cuvet dibersihkan dan dikeringkan. Kemudian mengatur panjang gelombang pada spektrofotometer. Selanjutnya cuvet dimasukkan ke spektrofotometer. Nilai transmittan diatur dan dibuat menjadi $100 \%$, dengan memutar tombol pengatur sinarnya.

\section{Pengukuran klorofil}

Larutan klorofil dituangkan ke cuvet sampai garis batas, permukaan cuvet dibersihkan dengan tissue dan dimasukkan ke spektrofotometer. Selanjutnya nilai absorbansi $(\mathrm{A}=\mathrm{OD})$. Dicatat untuk setiap panjang gelombangnya. Kandungan klorofil diukur dengan spektrofotometer UV-Vis pada $\lambda$ 649 dan 665 nm. Kadar klorofil total dihitung dengan rumus Wintermans dan De Mots :

Klorofil a $(\mathrm{mg} / \mathrm{L})=(13,7 \times \mathrm{OD}$ $665)-(5,76 \times$ OD 649)

Klorofil b $(\mathrm{mg} / \mathrm{L})=(25.8 \times$ OD 649) - (7,7 x OD 665)

Klorofil Total $(\mathrm{mg} / \mathrm{L})=20(\mathrm{OD}$ 649) + 6,1 (OD 665)

Keterangan : OD (optical density) atau nilai absorbansi klorofil

\section{Perhitungan Luas Daun}

Luas daun diukur menggunakan metode gravimetri yaitu dengan cara membuat replika daun pada kertas milimeterblok dan ditimbang beratnya, lalu dibandingkan dengan berat kertas standar. Luas daun dihitung berdasarkan persamaan (Sitompul dan Guritno, 1995) :

Luas daun $=\frac{\text { bobot replika daun }}{\text { bobot kertas } 10 \mathrm{~cm} \times 10 \mathrm{~cm}} \times 100 \mathrm{~cm} 2$

\section{HASIL PENELITIAN}

Kandungan klorofil daun api-api meningkat seiring bertambahnya umur daun (Gambar 1). Pada sampel 1 sampai dengan sampel yang ke-3, kandungan klorofil a dan $b$ semakin meningkat dari bagian ujung sampai pada bagian pangkal. Gambar 2 menunjukkan bahwa adanya peningkatan jumlah rata-rata kadar klorofil total dan rata-rata ukuran luas daun. Pada sampel yang terletak di ujung daun, kadar 
klorofil total pada sampel 1 yaitu $5,4 \mathrm{mg} / \mathrm{L}$ dan semakin meningkat pada bagian pangkal daun yaitu sebesar 12,4 mg/L. Begitu pula ratarata ukuran luas daun pada sampel 1 bagian ujung daun yaitu $25 \mathrm{~cm}^{2}$ dan semakin meningkat luas daunnya pada bagian pangkal daun yaitu 112 $\mathrm{cm}^{2}$.

Berdasarkan hasil output yang dihasilkan dari analisis bivariat menggunakan aplikasi spss, hubungan korelasi antara kadar klorofil total dan luas daun ditunjukkan dengan nilai korelasi 0,948 yang artinya korelasi signifikan karena mendekati 1. Maka dapat disimpulkan terdapat korelasi yang positif antara kadar klorofil total dan luas daun. Artinya jika luas daun bertambah di setiap tingkat perkembangan daunnya, maka kandungan klorofil totalnya juga akan semakin meningkat.

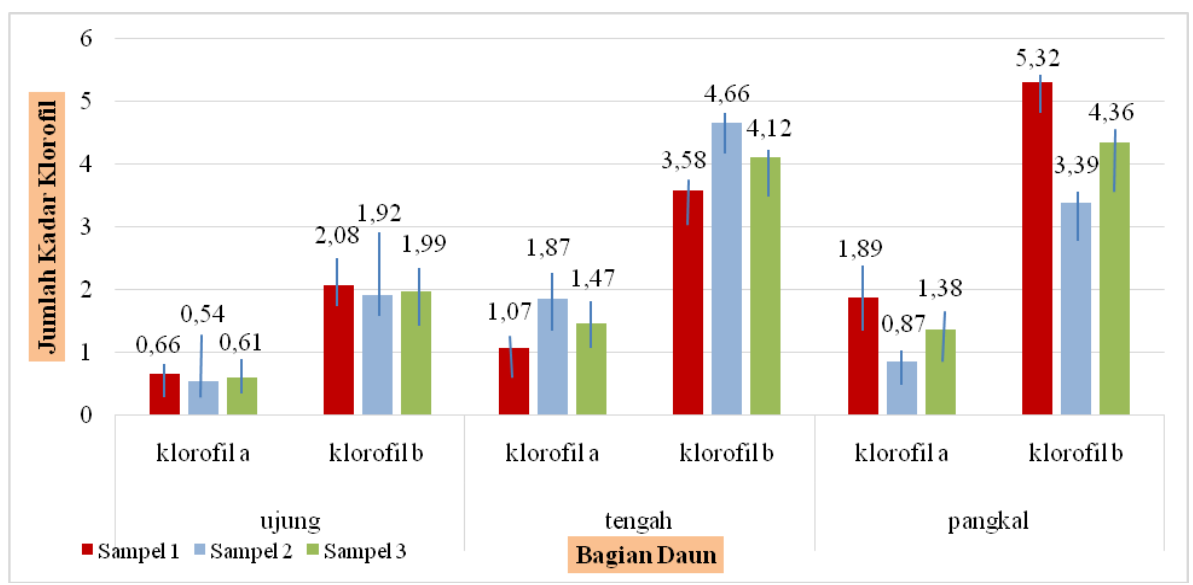

Gambar 1. Kadar klorofil a dan klorofil b daun Avicennia marina

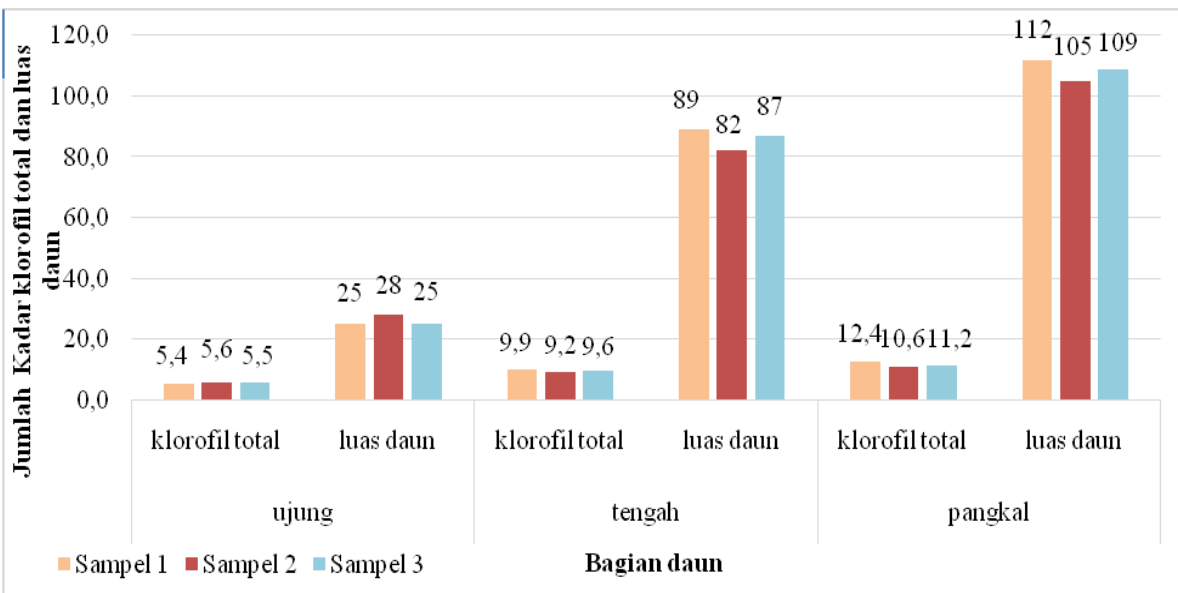

Gambar 2. Rata-rata klorofil total dan rata-rata luas daun Avicennia marina 


\section{PEMBAHASAN}

Klorofil penting bagi tumbuhan untuk melaksanakan fotosintesis dan menghasilkan energi. Klorofil tidak larut dalam air, melainkan larut dalam etanol, methanol, eter, aseton, bensol dan kloroform. Untuk memisahkan klorofil a dan klorofil b beserta pigmen - pigmen lainnya seperti karotin atau xantofil, duji menggunakan teknik spektrofotometri. Sifat fisik klorofil adalah menerima dan atau memantulkan cahaya dengan gelombang yang berlainan. Klorofil banyak menyerap sinar dengan panjang gelombang antara 400-700 $\mathrm{nm}$, terutama sinar merah dan biru (Seitz, 1987 dalam Prastyo dan Laily, 2015).

Pada Gambar 1, kandungan klorofil a dan b semakin meningkat dari bagian ujung sampai pada bagian pangkal. Hal ini disebabkan karena pada daun bagian ujung ada yang berwarna hijau bercampur kuning kecoklatan. Warna daun kecoklatan menunjukkan adanya pigmen karotenoid yang merupakan pigmen dominan pada ujung daun.

Pigmen karotenoid berperan sebagai pigmen tambahan yang membantu klorofil dalam menyerap energi cahaya. Biber (2007) dalam Setiari dan Nurchayati (2009) menyatakan bahwa umur daun dan tahapan fisiologis suatu tanaman merupakan faktor yang menentukan kandungan klorofil. Pada penelitian Sumenda et al (2011) disebutkan bahwa klorofil pada daun yang masih muda masih berupa protoklorofil dan akan berubah menjadi hijau sepenuhnya setelah transformasi protoklorofil.

Perhitungan konsentrasi klorofil a dan klorofil b menggunakan spektrofotometer pada gambar 1 menunjukkan bahwa nilai tertinggi konsentrasi klorofil terdapat pada klorofil $b$, baik pada sampel pertama maupun pada sampel yang ketiga. Hal ini menunjukkan terjadinya sintesis klorofil $b$ dari klorofil a dengan jumlah yang besar yang diikuti dengan berkembangnya daun tersebut. Menurut Sumenda, et al (2011), sintesis klorofil b terus berlanjut bersamaan dengan perkembangan daun yang ditandai dengan berubahnya warna daun hijau muda menjadi hijau tua. Peningkatan kandungan klorofil $\mathrm{b}$ pada tanaman berkaitan dengan peningkatan protein klorofil sehingga akan meningkatkan efisiensi fungsi antena fotosintetik pada Light Harvesting Complex II (LHC II) (Setiari dan Nurchayati, 2009).

Kemampuan daun untuk berfotosintesis juga akan semakin meningkat sampai daun berkembang penuh dan kemudian mulai menurun secara perlahan. Daun tua yang hampir mati akan menjadi kuning dan tidak mampu berfotosintesis karena rusaknya klorofil dan hilangnya fungsi kloroplas (Sestak, 1981 dalam Pratama \& Laily, 2015). Faktorfaktor yang berpengaruh terhadap 
pembentukan klorofil antara lain adalah, cahaya, gen, unsur $\mathrm{N}, \mathrm{Mg}$, Fe sebagai pembentuk katalis dalam sintesis klorofil (Pratama dan Laily, 2015).

Fotosintesis yang terjadi di daun membutuhkan dua bahan utama yaitu $\mathrm{CO}^{2}$ dan $\mathrm{H}_{2} \mathrm{O}$. Reaksi utama fotosintesis terjadi di kloroplas dengan agen utamanya yakni klorofil. Pembentukan klorofil pada daun paling banyak dipengaruhi oleh cahaya matahari. Selain itu, umur daun juga mempengaruhi kadar klorofil pada suatu daun. Pada awal perkembangan daun, aktivitas meristem daun menyebabkan terjadinya perpanjangan daun. Perpanjangan daun berikutnya terjadi sebagai akibat aktivitas meristem interkalar, sehingga dapat diartikan bahwa bagian pangkal daun lebih tua dibandingkan ujung daun yang berakibat pada perbedaan jumlah klorofil yang dikandungnya (Hidayat, 2008 dalam Pratama dan Laily, 2015).

Saiful (2007) dalam Setiawati et al (2016) menyatakan bahwa jumlah kadar klorofil tdak hanya dipengaruhi oleh jumlah pigmennya saja, tetapi juga dipengaruhi oleh luas ukuran daun. Menurut Gembong (2005), bertambahnya luas ukuran daun terjadi karena bertambahnya jumlah dan ukuran sel. Hal ini menunjukkan bahwa peningkatan rata-rata kadar klorofil total dan rata-rata luas daun bertambah seiring dengan tingkat perkembangan daunnya.

Pada penelitian yang telah dilakukan oleh Setiawati et al (2016) membuktikan adanya kenaikan jumlah kandungan klorofil dan rata-rata luas daun lampeni sesuai dengan tingkat perkembangan daun yang berbeda. Semakin besar ukuran daunnya maka kadar klorofilnya pun semakin tinggi. Menurut Baker dan Hardwick (1973) dalam Setiawati et al (2016) bahwa kadar klorofil akan meningkat pada saat klorofil per satuan luas daun mencapai tingkat maksimum sebelum akhirnya daun berhenti berkembang.

\section{KESIMPULAN}

Berdasarkan hasil penelitian yang telah dilakukan, maka kesimpulan dari penelitian ini adalah kandungan klorofil daun apiapi berbeda pada tiga daerah perkembangan yang berbeda, yaitu ujung, tengah dan pangkal daun. Terdapat korelasi yang positif antara luas daun dan kadar klorofil total yang artinya jika luas daun bertambah di setiap tingkat perkembangan daunnya, maka kandungan klorofil totalnya juga akan semakin meningkat.

\section{UCAPAN TERIMA KASIH}

Ucapan terima kasih ditujukan kepada LPPM Universitas PGRI Adi Buana yang telah mendanai penelitian ini melalui Penelitian Hibah Adi Buana. 
DAFTAR PUSTAKA

Abdilah, F., I. Raya dan A. Ahmad. 2014. Pengujian Daya Antioksidan dan Sifat Toksisitas Ekstrak Co (II) Turunan Klorofil. Artikel Ilmiah. Jurusan Kimia, Universitas Hasanuddin, Makasar.

Baker, N.Y dan K. Hardwick. 1973. Biochemical and Physiological Aspects of Leaf Development in Cocoa (Theobroma cacao). New Phytol (72): 1315 1324.

Biber, P.D. 2007. Evaluating a Chlorophyll Content Meter on Three Coastal Wetland PlantmSpecies. Journal of Agricultural, Food and Environmental Sciences. Volume 1, Issue 2.

Gembong, Tjitrosoepomo. 2005. Morfologi Tumbuhan. Yogyakarta: Gadjah Mada University Press.

Gogahu, Y., N. S. Ai, P. Siahaan. 2016. Konsentrasi Klorofil Pada Beberapa Varietas Tanaman Puring (Codiaeum varigatum L.). Jurnal MIPA Unsrat Online. Vol. 5(2): 76-80.

Hendriyani, I.S dan N. Setiari. 2009. Kandungan Klorofil dan Pertumbuhan Kacang Panjang (Vigna sinensis) Pada Tingkat Penyediaan Air yang Berbeda. Artikel Penelitian. Jurusan Biologi
FMIPA Universitas

Diponegoro. Semarang.

Pratama, A.J dan A.N. Laily. 2015. Analisis Kandungan Klorofil Gandasuli (Hedychium gardnerium Shepard ex Ker-Gawl) Pada Tiga Daerah Perkembangan Daun Yang Berbeda. Prosiding Seminar Nasional Konservasi dan Pemanfaatan Sumber Daya Alam Pendidikan Biologi, Pendidikan Geografi, Pendidikan Sains, PKLHFKIP UNS 2015: 216-219

Prastyo, K.A dan A.N. Laily. 2015. Uji Konsentrasi Klorofil Daun Temu Mangga (Curcuma mangga Val.), Temulawak

(Curcuma xanthorriza), dan Temu Hitam

(Curcuma aeroginosa) dengan Tipe Kertas Saring Yang Berbeda Menggunakan Spektrofotometer.

Prosiding Seminar Nasional Konservasi dan Pemanfaatan Sumber Daya Alam Pendidikan Biologi, Pendidikan Geografi, Pendidikan Sains, PKLHFKIP UNS 2015: 188-191.

Processes Limiting

Plant

Productivity. London: Butterworths.

Setiari, N dan Y. Nurchayati. 2009. Eksplorasi Kandungan Klorofil pada Beberapa Sayuran Hijau Sebagai 
Alternatif Bahan Dasar Food Supplement. Bioma Vol 11 (1): 6-10.

Setiawati, T, I.A. Saragih, M. Nurzaman dan A.Z. Mutaqin. 2016. Analisis Kadar Klorofil dan Luas Daun Lampeni (Ardisia humilis Thunberg) pada Tingkat Perkembangan yang Berbeda di Cagar Alam Pangandaran. Prosiding Seminar Nasional MIPA 2016: 122-126.
Sumenda, L. H.L. Rampe, F.R. Mantiri. 2011. Analisis Kandungan Klorofil Daun Mangga (Mangifera indica, L.) pada Tingkat Perkembangan Daun yang Berbeda. Bioslogos Vol. 1(1):20-24. 